\title{
Inter-Sentential Patterns of Code-Switching: A Gender-Based Investigation of Male and Female EFL Teachers
}

\author{
Malik Ajmal Gulzar ${ }^{1}$, Muhammad Umar Farooq ${ }^{1} \&$ Muhammad Umer $^{2}$ \\ ${ }^{1}$ English Language Center, Taif University, Taif, KSA \\ ${ }^{2}$ Foreign Languages Dept., Taif University, Taif, KSA \\ Correspondence: Malik Ajmal Gulzar, Assistant Professor, Supervisor of Curriculum Development and Research \\ Unit, English Language Center, Taif University, Taif, KSA. Tel: 966-582-927-088. E-mail: agmsfa@gmail.com
}

\author{
Received: September 30, 2013 Accepted: October 28, 2013 Online Published: October 31, 2013 \\ doi:10.5539/ies.v6n11p144 \\ URL: http://dx.doi.org/10.5539/ies.v6n11p144
}

\begin{abstract}
This article has sought to contribute to discussions concerning the value of inter-sentential patterns of code-switching (henceforth ISPCS) particularly in the context of EFL classrooms. Through a detailed analysis of recorded data produced in that context, distinctive features in the discourse were discerned which were associated with males' and females' inter-sentential switches. By looking at language choice against the background of this patterning, one can understand the complexity of the occurrences of inter-sentential switches in the classroom. A few studies on ISPCS in EFL classrooms have been hardly conducted to determine the gender-based inclination among EFL teachers. For this reason, there is a lack of awareness on the part of English language teachers about the qualitative and quantitative use of ISPCS in the context of Pakistani EFL classrooms. For the purpose of investigation, the ethnography of interaction was selected as a research design to record and transcribe the sessions of eight resource persons of Allama Iqbal Open University. During the analysis, the results of the study indicated that all the male and female teachers switched code in the boundary of ISS (henceforth ISS). Moreover, in the light of the data analysis, trends were determined among male and female teachers for the patterns of inter-sentential switches. In short, this paper tried to develop an understanding about the phenomenon of inter-sentential switches to get a better insight of the teaching/learning situation in the EFL context.
\end{abstract}

Keywords: bilingualism, EFL classrooms, Inter-sentential switches, second language acquisition

\section{Introduction}

Code-switching appears intertwined with a range of inter-linguistic phenomena in language contact from strict interference to several other kinds of language mixture. Code-switching has been studied primarily in everyday talk and in social interaction between members of a particular speech community which implies a synchronic approach. In this study, the researchers aim has been to approach the ISS as they emerge in the EFL classrooms, which is a complex linguistic repertoire in terms of both linguistic resources and verbal genres. The arguments in this article are based both on theoretically-oriented works and on the data collected from research work conducted to investigate ISPCS in EFL classrooms. The connecting thread in this work is the need to understand the differences in the usage of inter-sentential switches between the interactants of EFL classrooms. Classroom life is socially constructed and it also acknowledges the dominance of social interactions in all that occurs in classrooms. Interactants interact with each other as members of the class and construct different patterns of classroom communication which define interactional and interpersonal behaviours of those interactants in that particular situation. Learning in classrooms is not merely a process of learning a language, but it is also a reflection of language through which teachers determine their code to cater for their students' need by applying different codes of interaction in the domain of EFL classrooms (Green, Kantor, \& Rogers, 1990, p. 333-364). Therefore, it is a fundamental requirement of the EFL classrooms to investigate the trends of male and female teachers about the use of the ISS. Despite the significance of the phenomenon of ISS, an insufficient attention is paid to the dimensions of ISPCS. Focusing on the same deficiency, the researchers tried to develop more understanding of ISS in the context of EFL classroom. 


\subsection{Aims of the Study}

The following points are summarized by the researchers as the objectives of the study:

i. To identify EFL male and female teachers' patterns of ISPCS in the EFL classrooms;

ii. To explain how male and female teachers accomplish their interaction in the EFL classrooms by using ISPCS; and

iii. To define the ways in which EFL teachers achieve proper coordination of communication in the interaction of EFL classrooms.

\subsection{Operational Definitions of Code-Switching}

Gumperz (1982, p.59) defines code-switching in these words: "The juxtaposition within the same speech exchange of passages of speech belonging to two different grammatical systems or sub-systems". Valdes-Fallis (1981) states that code-switching may be defined as the alternating use of two languages at the word, phrase, clause, or sentence level. These two definitions are considered as operational definitions for the present study.

\subsection{Research Questions}

The following research questions are used to guide the work under study:

Q.1. How can ISPCS verify the choice of male and female teachers in the discourse of EFL classrooms?

Q.2. Does inter-sentential switches differ among the male and female EFL teachers?

\subsection{Code-Switching In EFL Classrooms}

Code switching may be considered in relation to language acquisition. A number of research works have been postulated as to how an individual attains language and these are discussed in the following lines. Chomsky (1975 \& 1979) suggests that language acquisition takes place as the brain matures and exposure to the appropriate language is obtained. Chomsky also suggests that people are aided by innate universal language structures and as children learn, they realise how to express the underlying universal structure according to their particular culture, as described by Bootzin, Bower, Zajonc and Hall (1986). Behaviourists do not accept this biological theory and suggest that language acquisition is a verbal behaviour which is an example of operant conditioning, as advocated by Skinner (1957). Behaviourists argue that individuals are reinforced by their own speech which matches the reinforcement of providers of affection during childhood. A point to note here is that the theories rely on exposure to appropriate samples of the language. And the same is true while acquiring second language, teachers switch code as a strategy to compensate the deficiency on the part of students. For the same reason, communication in English can be a barrier for many second-language learners because English serves both as a content subject and also as the means of instruction in classrooms (Brice, 2001, p. 8). Martin-Jones (2003, p. 6) explains that

"Bilingual teachers and learners routinely use code-switching as an additional meaning-making resource within the ongoing flow of classroom talk. Code-switching is used to demarcate different kinds of discourse: to signal the transition between preparing for a lesson and the start of a lesson; to distinguish classroom management talk from talk related to lesson content; to specify a particular addressee; to change footing or to make an aside or to distinguish the reading aloud of a text from talk about the text".

Martin-Jones (1995) explains that two studies by Milk (1984) and Guthrie (1984) shifted the focus to the accomplishment of interactive acts in EFL classroom discourse. She further claims that "more attention was now given to the ways in which teachers and learners get things done with two languages in classrooms and to the way in which language values are transmitted through communicative choices" (p. 93). Milk's work used an adapted version of Sinclair and Coulthard (1975 cited in Martin-Jones, 1995) to record a twelfth grade civics class activity, where a Mexican-American teacher used a bilingual pattern to teach in that class. With the help of the recorded data, he focused on the patterns of the code-switching. According to Martin-Jones (1995), Milk's study claimed that English was the dominant language and this dominance put the majority of Spanish students at a disadvantage. Cook (1989) provides another method of using code-switching as a second language teaching tool through reciprocal language teaching. This method requires students to switch languages at predetermined points, putting students in pairs who want to learn each other's language. Thus the students alternate between the two languages and exchange the roles of student and teacher. A similar system may also be used whereby the teacher uses code-switching by starting the lesson in the first language and then moving into the second and back. Cook (1991) describes that this practice makes the lesson as communicative as possible and is similar to the 'New Concurrent Approach' (NCA) presented by Rodolpho Jacobson. The approach helps teachers to balance the use of language switch at certain key points, such as during important concepts, when students are getting 
distracted, during revisions or when students are praised and told off. On the basis of this view, switching may be used as an effective teaching strategy for second language learning (Skiba, 1997). Skiba (1997, p. 10) delineates the function of code-switching and claims that it allows the students to become autonomous over a period of time whereby the teaching is reciprocated from the teacher to the student. Cook (1991) suggests that the use of code-switching in the classroom would provide for a bilingual norm whereby code-switching is seen to be an acceptable method of communication. Students then would feel comfortable switching languages within normal conversations providing for a bilingual society. It has also been outlined that code-switching may facilitate language development as a mechanism for providing language samples and may also be utilised as a teaching method for teaching second language. Jacobson's (1983) view is that languages are best mixed in the classroom by code-switching, if languages are separated then teachers will have to teach each subject twice once in English and once in Spanish. Moreover, language separation is based on content and then it will be impossible to decide which subject should be taught in which language. According to Jacobson's (1983, p. 5) NCA, teachers should be permitted to use inter-sentential code-switching. Jacobson fears that in intra-sentential switches a child is not exposed long enough to any one language and then it would be difficult for him to derive the grammatical, semantic and lexical rules of both English and Spanish. Thus with the settlement of these issues, both teachers and students can establish classroom discourse in accordance with the requirement of the EFL language learning paradigms. McLaughlin, Blanchard and Hammink (2000, p. 14) maintain that code-switching significantly enhances the expressive capacity of an individual; and Genesee, Paradis and Crago (2004) also urge educators to recognise the communicative and metaphorical values of code-switching. Code-switching, according to these researchers is a device of 'great semantic power'. Hammink (2000) further clarifies that children who code-switch are expanding their code-switching strategies from the merely communicative to the rhetoric, and a well-informed educator can assist in this development, just as he/she assists the development of other communicative capacities of his/her students. The need for a better understanding of code-switching phenomenon among classroom teachers is also emphasised by Valdes-Fallis (1978) in these words: "An understanding of code-switching is especially important for those classroom teachers whose students include Spanish/English bilinguals" (p. 124). Very little has been said about the characteristics of bilingual speakers who habitually alternate between two languages in their communities. According to Aguirre (1988), language alternations or code-switching in the classroom are obvious and unavoidable with culturally and linguistically diverse children and special educators should regard language alternations as a communicative strategy employed by the students learning a second language. Unfortunately, a true understanding of language alternation behaviours is a phenomenon still not understood by professionals in education and it may be perceived as a controversial issue (Baker, \& Jones, 1995). However, it is the consensus of many in the field of bilingual education that it is a normal occurrence, and its use as a language choice in instruction is perfectly legitimate (Brice, 2000). Hammink (2000, p. 8 cited in Macswan 1999, p. 47) clarifies its significance and claims that children's attitudes toward code-switching are greatly affected by the attitudes of their caregivers. Recognition on the part of the teachers of the expressive power of code-switched discourse and the sophisticated linguistic knowledge required to effectively employ the mode, should serve to alter the prejudicial opinions they have about the practice.

It was observed by Haugen (1987) that code-switching was consistently ranked as least acceptable by teachers. Moreover, the researchers agree with these comments that bilingualism is misunderstood by educators and course developers and due to this teacher misrepresents language processes and cannot devise lesson plans based on the balanced use of languages (Hamers, \& Blanc 1989). So, it is essential to make teachers and educators understand the utility and benefits of code-switching in the EFL classrooms. These are just some of the ways in which bilingual teachers and learners negotiate their way through classroom interactions as they attempt to make sense of each other's contribution. Martin-Jones (2003, p.7) explains that "with the passage of time, particular interactional routines get established, class by class, and bilingual teaching/learning events take a particular shape". It has been found that participant-related switching by learners in classroom interaction often consists of what Lipski (1978, p. 76) describes as "an attempt to override communicative stumbling blocks by falling back on L1". Participant-related switching is also used by teachers in a "heterofacilitative" capacity (Romaine, 1989) anticipating that learners would not understand an upcoming utterance if it were in the target language, they fall back on L1. Indeed, participant -related code-switching has been found to predominate among both learners and teachers in classrooms as diverse as bilingual education programmes for linguistic minority children in the United States (Zentella, 1981). 


\section{Research Methodology}

The main research design selected for this study was ethnography of communication and this design helped the researchers to explore ISS in the EFL classroom. These interactional patterns helped the researchers to discover and describe ISS of both male and female teachers. Ethnography of research is selected for the study keeping in view "HOW" and "WHY" nature of the research questions. Also, it was a prerequisite to explore the phenomena as non-participatory observers, and this strategy was mainly adopted to observe the trends of the ISS between male and female teachers in the EFL classrooms. Sessions for teachers were audio recorded after getting approval from each of the resource persons. Keeping in view the parameters of heuristic research, the sessions were observed and recorded without restricting the natural flow of the EFL classroom interactions. The population of the study was selected from the EFL classrooms of Allama Iqbal Open University. Eight teachers were identified as additive bilingual whose two languages combine in a complementary and enriching fashion (Li Wei, 2000, p. 6). The study was delimited to explore and analyse the ISPCS related to EFL classroom discourse to explore the gender based trends of this kind of ISS.

\subsection{Data Collection Strategies}

Audio-recording of the sessions of the EFL classrooms was used as tools for data collection. Eight sessions were observed, recorded, transcribed, and almost twelve hours recording of the EFL classrooms was made in total. Recorded materials proved very successful for the purpose of description and analysis of data as Burns (1999, p. 94) clarifies that

"Audio and video recordings are techniques for capturing in detail naturalistic interactions and verbatim utterances. Used in the classroom, they are, thus, very valuable sources of accurate information on patterns of interactional behaviours which may not be obvious during the actual teaching process."

The researchers used the audio recording repetitively to replay the events to describe and analyse the data to determine trends of the ISS between determined participants.

\subsection{Data Analysis}

For the purpose of analysis, all the objectives of the study were identified by the specified theme to infer the conclusion from the findings. Audio-recording was used as an important tool at the time of analysis of the data. According to Eisner (1991) "note-taking and audio-taping are crucial tools in conducting any qualitative research because they provide the researcher with reminders, quotations, and details for both descriptions and interpretations". The researchers used transcription conventions used by Van Lier (1988). The purpose of using these transcription conventions was to avoid any confusion and to communicate what actually had happened in the classrooms. The researchers added some symbols from his own side to define all the aspects of the sessions and these added symbols are shown with asterisks (see Appendix \# 1). After the transcription of the sessions, the first step followed by the researchers in analysis was to formulate inferences from the collected data. The foremost theme of the study is the investigation of inter-sentential patterns of code-switching in the EFL classrooms and this fundamental theme helped the researchers throughout at different stages of research.

\section{Discussion on Results and Implications}

In the process of analysis of ISPCM, the following different patterns of switches were observed: code-switching from English to Urdu, and code-switching from Urdu to English. The researchers found some obstacles during the analysis of ISPCS. Some of the teachers' utterances overlapped with intra-sentential patterns of code mixing (hereinafter ISPCM) and had dual implications for more than one utterance. And it was difficult to determine whether the teachers switched their code for ISPCM or ISPCS. It caused trouble to the researchers during the analysis of the data and to sort out this problem, the researchers set the definition of romaine as a yardstick to differentiate between these two closely connected patterns of switches. In the following sections, the selected representative examples of the teachers' ISPCS are presented to determine the trends between male and female teachers.

\subsection{Male Teachers' Intra-Sentential Patterns of Code Switching}

\subsubsection{Inter-Sentential Pattern of Code Switching of Male Teacher No.1}

The session of male teacher No.1 provided some examples of ISS and these switched utterances were most of the time at sentence level. 
Table 1. Inter-sentential pattern of code-switching of male teacher No.1

\begin{tabular}{ll}
\hline Theme & Number of utterances \\
\hline Inter-sentential pattern of CS & 13 \\
\hline
\end{tabular}

The following examples of code-switching are taken from transcription No.1 to give the break-up of his switched utterances.

27 T: I think most of us have watched ( ). I give credit to Amir Khan for producing such a good film, $\underline{\text { Tarev }}$

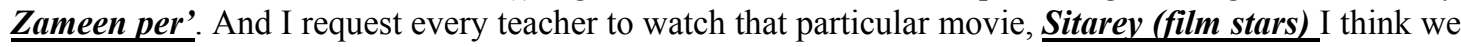
have already talked about - (AP ne dekhi hai?) Have you watched?

$\mathrm{T}$ : $\mathrm{OK}$, the parents actually, due to certain reasons and, (wo pav nahi kerna chahtev) thev don't want to pav. They don't want to have the extra burden of that child because of this reason that. (wo doosrav school mai ley aatey hain) they take him to another school I found a child should be handed into grade $\mathrm{H}$, simple is that.

$\mathrm{T}$ : The third type, in the characteristics of test is discrimination ( ) (specially schoolon main, collegon main esa ho jata hai) usuallv it happens in schools and colleges, all the students are very happy, it was so easy ( $k$ marev bhi marks aa gave) that even I got marks. ( ). Sometimes it is so difficult that it becomes difficult at least for a Student ( ) and sometimes it's easy for everybody ( $k$ wo jo parhney wala baccha hai or io nahi perhnav wala baccha) a child who works hard, and a child who never works hard, they're all get marks together //

T: OK, we will give $40 \%$ for their exit something 25 percent will get D grade and some material, intentionally give some questions for discrimination among those. (theek hai na to hum kva kertev hain k) Right so what we do is that those who really want to get through, they go for $40 \%$.

3.1.2 Inter-Sentential Pattern of Code-Switching of Male Teacher No.2

In this session, male teacher No.2 provided many examples of ISS while delivering his session in the EFL classroom. He code-switched approximately fifty five times in his session and provided an extensive variety of ISS. The following table provides calculations how he switched his utterances for ISS. The following table provides break-up of his switched utterances.

Table 2. Inter-sentential pattern of code-switching of male teacher No.2

\begin{tabular}{ll}
\hline Theme & Number of utterances \\
\hline Inter-sentential pattern of CS & 55 \\
\hline
\end{tabular}

In the following excerpts, representative examples are taken from transcription No.2 to highlight the examples of ISPCS:

27 T: We have to just cram it. (eik ratta lagana parta hai) We have to cram I used to do it like that.

106 T: Now, what I am doing is (dono haath laga ker paseena nikal raha hai, bera gharaq ho raha hai) Using both hands, sweating, spoiling oneself and the box is not just moving an inch.

108 T: Now, more than the name - what was his basic idea in linguistics? (kya kiya tha us ne?) What did he do?

112 T: I would like any one of you three people. ( koi baat ap btaive) You tell me something Noam Chomsky?

257 T: When I need to say something else, I say it is my way, but you understand a different thing. (ap kehtev hain aur mujhey ib ap jawab detey hain to main kehta hon mai ne yeh to nahi poocha ap se. No sir is ka matlab to yehi hai) You assert and when you answer me then I say that I did not ask you this one. No sir, it means the same.

326 T: (wo jo eik side rakhi hui hai na, who us ke saath hai) (The side that is placed over there, it's beside that). Everyone has finished? 
342 T: You give me a page that is checked.(jo keh abhi ap logon ne kiva hai) Which you people have done right now. So many things are lacking that only you know. Student can not say (ager who student keh pas jave to keh jee ghalati kis cheez ki nikali hui hai) If that goes to the student, he can not sav, what kind of error has been identified?

346 T: It has to be there in whatever proportion, but it has to be in the heart of the teacher. (tabhi kaam chalta hai) Then the work goes on. Now the single pages. (theek hai, yeh ap idher de dein, main udher deta hon) You give these |papers $\mid$ here. I give over there.

348 T: You understand. This is more important what you have done, unknowingly. (line mar di) Mark a line. Sometimes what happens is, if I see your paper, I cannot identify. (yeh line ooper wali ke neechev lagi hui hai va neechav wali ke) This line has been marked to clarifv the above sentence or the sentence $\underline{\text { below? }}$

350 T: (yahan pe ghalat kya hai) what is wrong overhere? You do not encircle.

(aur eik bar si cheez, hoti hai) and there is a big thing, appropriate, to the point. It's not hitting the right issue in that.

356 T: Sometimes, a student, rather we have got the practice, he comes up. (sir yeh kon si ghalati thi) Sir, which mistake was this? and we are thinking. (yeh mai ne kis cheez ko ghalat kiva tha baad mai) Which thing I had marked as wrong later on because, being teacher I play with the words

$364 \mathrm{~T}$ : I have been teaching in Beacon house (over years). (I know keh wo kva ker rahev hotev hain) I know that what are thev doing? and I quit that place.

396 T: When it comes to speaking and I want to say.(keh ye John sahab ki pakki adat hai keh wo cigaratte peetay hain) that it is Mr. John's firm habit that he smokes cigarette.

423 T: (hamein yeh pata hi nahi hota, hum parhana shuru ker detev hain) We do not know about it. We iust start teaching.

471 T: So many things are let unanswered. When I was doing all that (mai ne abhi bohat sari cheezein- veh kerna hai, who kerna hai) When I was doing all that - I have to do this and that. I could not do because I knew (ke do ghantoon ke andar) that within two hours, it would not be possible for me.

3.1.3 Inter-Sentential Pattern of Code-Switching of Male Teacher No. 3

Male teacher No.3 provided approximately eight examples of ISS. He did not provide an extensive variety of ISS.

The following table provides the details about the number of ISS.

Table 3. Inter-sentential pattern of code-switching of male teacher No.3

\begin{tabular}{ll}
\hline Theme & Number of utterances \\
\hline Inter-sentential pattern of CS & 8 \\
\hline
\end{tabular}

The following examples are taken from transcription No.3 to analyse the ISS related to EFL classroom discourse: (may be underlines/bold as above)

19 T: Which is a wonderland. (Eik ajeeb o ghareeb duniya) a strange mystry world.

26 T: I don't want you to sit in the dark. (ap yahan a jaein) you please come here.

65 T: (nahi) No??No? (h) There is something missing. Yeah, Shehzad?

187 T: Education is not just transmission of knowledge. (esa nahi hai keh) it's not like this that - )

$230 \mathrm{~T}$ : OK, I, I know, many of you are sitting with this, ( yar yeh to mujhey bhi pata tha)Oh my friend this is what I also knew.

328 T: Because I want to acknowledge each one of you. Right? Not that O' (yeh to is mai aa gya) It has been covered in that Right?

551 T: Stars on earth. Amir Khan - the way he enters the class () style. (Hamary agar koi kary ga () pagal ka putr andar a gaya ha.) If somebody will do it over here, ( ) a mad's son has come in.

$620 \mathrm{~T}$ : A one short event. (Waqia tha, guzar gaya ho ga.) That was the incident and had gone, No! It is a life long continuous process - Fine? 


\subsubsection{Inter-Sentential Pattern of Code-Switching of Male Teacher No.4}

This session provided small variety of ISS. It is important to clarify here that, in this session; the teacher's ISS were related to the informal discourse (An informal discourse is meant for other than classroom agenda items) of EFL classroom. The table given below presents the details about the number of uttered ISS.

Table 4. Inter-sentential pattern of code-switching of male teacher No.4

\begin{tabular}{ll}
\hline Theme & Number of utterances \\
\hline Inter-sentential pattern of CS & 9 \\
\hline
\end{tabular}

The following examples of code-switching are taken from transcription No.4 to highlight the ISS utterances.

29 T: Friday // that's the end of Solomon Brandy so, in the, to teach rhyming to children we can do, (jee) yes sir? So the biggest circle shows the stressed syllable. (Mai ne tum se poochna hei aakhir mai saara jo mai parhaa raha hon.) I'll ask you all in the end what I'm teaching. ( $\mathrm{h}$ )I'm teaching for you not for the rest of the class. (Sir bijli chali gai?) Sir is it electricity breakdown? ( . )

85 T: But I don't want to.... OK sir come on to next, next sir (. ) (ap is ko eik aur dafa dabaein.) Press it once again. So, (sir speaker key ooper eik dafa) sir, on the speaker once -

97 T: I have contacted him time and again, 'I've contacted him time and again'. So, (sir is ko zara,Speaker ko zara eik dafa kijeye ga) sir please, this one, play the speaker once please

112 T: (Dekh lein wo time ka thora sa) see we have time problem

118 T: (Agev ker dein, agev ker dein....agev ker dein... aur agev.) Forward it, forward it, forward it a bit more. Introducing sentence stress, right?? Any idea about sentence stress??

146 T: So switch on to next sir please, so this is an important, (wo pichla tha ya... yeh tha? Yeh ho gya is se agey chaltey hein.) Was it the last one? It's done; let's move on to the next.

164 T: Next ( . ) (agev, sir pichla, peechev is se. peechev, peechey is se.) Sir next, sir last one, the last one. These are unstressed words. (Next sir, agev, ageev chalein zara. Is ko zara play ker dein.) Forward it, a little bit more. Plav it please.

212 T: Stopped working?? (Do dafa karein na.) Do it twice. (.) (Nahi kaam ker raha?) Not working?? ( . ) OK what do you say?

224 T: Since the, the speaker knew that it was in South America so he wanted to reassure it. (Next karein sir (.) Yeh bhi usi ka hei, agev ker dein. Dekhein chalta hei?) Sir next please. It's the part of the same, forward it. See if it plays??

252 T: You make list... (sir eik minute is mein) sir please just a minute.... Let me give you, I would, I would like that... (sir thora sa time hai? thora sa ..han) Do we have a little time?

\subsection{Females' Inter-Sentential Patterns of Code-Switching}

\subsubsection{Inter-Sentential Pattern of Code-Switching of Female Teacher No.1}

In this session, the female teacher provided many examples of code-switching related to classroom discourse. In this session, female teacher No.1 provided many examples of ISPCS related to classroom discourse. In the case of this teacher, the ISS can be interpreted as a personal style of the teacher. Moreover, it just occurred due to the fact that it was her personal style as a bilingual teacher. Code-switching occurrences depend on the social situation requirement or stylistic preferences. A Bilingual speaker code-switch to their weaker language to add colour or blends the two linguistic systems according to his/her needs or preferences (Valdes-Fallis, 1978). Switches of this session truly reflect the situation as mentioned by Valdes-Fallis.

Table 5. Inter-sentential pattern of code-switching of female teacher No.1

\begin{tabular}{ll}
\hline Theme & Number of utterances \\
\hline Inter-sentential pattern of CS & 68 \\
\hline
\end{tabular}


The following examples are extracted from the transcription of female teacher No.1 to highlight the inter-sentential patterns of code-switching:

46 T: What I need to do is give you confidence ask me a question $\underline{k \text { miss yah wali baat samajh mai nahi }}$ aai )Miss I could not understand your point (). (Ager ap mujh se yeh poochein ge to mai yeh nahi kahoon gi k ager ap ko nahi pata to ap vahan kva ker rahev hain?) When you ask me anything, I won't say what are you doing here if you don't know anything ( . ) that is something that the teacher must not do at all, yes?

56 T: Kindly accept me I'm sorry how I spoke. OK you I can always ( ) (kidher likha hai is ko) where have you written it?

88 T: (Koi bhi nahi kerv ga.) No one will do that. (Students nahi karein gev) the students won't do that. You know up to the school level reading is a passive activity

90 T: (Book kolein, parhein, neechey sawal likhein hain un ko karein) Open the book, read and answer the questions written below.

129 T: And you come out and say (Intni buri class hai dekhi nahi zindagi mai such a bad class (h). Class kesav buri ho sakti hai, buri teacher hoti hai,) How can a class be bad? It's the teacher who is bad. It's always the teacher not the class, a class is a reflection of the teacher.

135 T: I should blame myself, right? It's very easy to say (k aur bhi to hain wahan teachers wo kyon nahi dekhtin? Mujhev us main) there are manv other teachers, why don't thev have a check. In that I.

141 T: It is satisfaction and enjoyment in teaching are depends upon leading students to cooperate. (ager ap niklein or ap ne sir pakra ho $k$ coffee bhi chahive jee, ap ko coffee peeni hai ya chaye peeni hai, sir dukh raha hai class parha $k$. Eik class) If you come out of the class and you need coffee or tea because you are having headache because of teaching just one class - (.)

161 T: The moment (ap ko kaha jata hai $\boldsymbol{k}$ jee 5 minute $\boldsymbol{k}$ live veh parhein, adhev tau bateein ker rahev hon ge. Ab yeh barron ki baat ker rahey hain hum.) When you are told to read something in five minutes, half of you start talking. Here we are talking about adults.

167 T: (ap ne maon ko nahi suna "chup ker k betho ab eik lagaon gi” aur baccah bheen bheen ker raha hai ( $h$ ) aur laga bhi nahi rahi aur kahev bhi ja rahi hain, "chup ker $k$ betho, eik lagaon gi") have vou heard the mothers saving, "be quite or I'll slap you" and the child is crying bitterly. She is not slapping him but just asking him to be quiet

219 T: You would move around, fine, see what the student is doing probably

point out (k yeh point theek nahi hai,)That this point is not correct. Not actually tell the students (what to write). (kuch to kaam ker rahev hain na) at least thev are doing something.

229 T: Agreed, agreed, // (lekin dekhein baat to ho rahi thi) but we were talking about that teaching is a work of heart and nothing else.

\subsubsection{Inter-Sentential Pattern of Code-Switching of Female Teacher No.2}

This session provided numerous examples of ISS and in this session teacher used mother tongue for an extended span of time. The reason for the use of mother tongue may be that she had a limited experience of teaching at the university level. As Auer (1984) defines that "one should not expect that every alternation case would have a particular function or have to do conversational work, because some cases of language alternation may be the result of a lack of competence in one of the languages." The same situation was observed in her session as mentioned by Auer. She was the first teacher who provided examples of ISS. She switched from Urdu to English to perform different functions due to her continuous delivery of session in Urdu. Crystal (1987) while explaining the similar situation claims that there are a number of reasons for switching from one language to another and the first of these is the notion that a speaker may not be able to express him/herself in one language. So, he/she switches to the other code to compensate for the deficiency. In the case of this female teacher, Crystal's first reason justifies the style of this teacher because she continuously used the mother tongue.

The following table provides approximate details of the ISS utterances of teacher No.2. 
Table 6. Inter-sentential pattern of code-switching of female teacher No.2

\begin{tabular}{ll}
\hline Theme & Number of utterances \\
\hline Inter-sentential pattern of CS & 82 \\
\hline
\end{tabular}

The following examples are extracted from the transcription of female teacher No.2 to highlight the ISS:

3 T: What you get from the very word, "Writing Skills" (Kya cheez aati hei zehan main?) what comes in your mind?

40 T: I cannot move ahead if the thing is just restricted to a point. (Ager koi cheez yahan ruk gai hai to agev jana fuzul hai.) it is useless to move forward if something is not clear at this point. Clear or any question? What is writing skills?

42 T: (Ap ko bohat clear hua hai, sab se zyada ap ne inkaar kiva hai.) everything is clear to you that you have refused to sav anvthing what is writing skills?

72 T: Any novel regarding from your literature, regarding from your school module? (Kahein se bhi koi esi book mujhey paata ker dijiye io $k$ sab ne parhi ho) suggest any book to me that everyone has read in this class.

79 T: It's a Brazilian writer a very well-known writer, he can turn the world upside-down (jis ko kaha gya $\underline{h a i k) h e ' s ~ c o n s i d e r e d ~ t o ~ b e ~ h e ' s ~ t h e ~ b e s t ~ s e l l e r ~ i n ~ t h e ~ w o r l d ~ K u c h ~ l o g ~ a a m ~ l o g o n ~} k$ liye likhtey hain, $k$ merey khavlat itney aam hein $k$ us ko har koi parhey

83 T: There must be a building up communication between the writer and reader. (Har eik ka talaaq hota hai apas main) evervone has got a relationship with each other .

121 T: Right? (K Ho sakta hai $\boldsymbol{k}$ in bacchon $k$ a dil chahta ho $\boldsymbol{k}$ in $\boldsymbol{k}$ pass games hon, computer games hon, video games hon lekin) these kids may want to have different games, computer games, video games but II

226 T: Hardly two or three students have mentioned two or three pictures, why? (ap se sirf veh nahi kaha tha k eik tasweer le lein,) you were not told to take only one picture that was a very ()

252 T: (Yeh to ap ne slogan diva hai fair and lovely ka, abhi ap ne story to btai nahi.) vou have just given the slogan of fair and lovely, you still have to tell the story

281 T: (Eik jo larki gaari ko ssaf ker $k$, usev kitni bachat ho jave gi? Kitna?) how much a girl can earn bv cleaning the cars? How much she can earn?

339 T: (Urdu ko khatam nahi kerna chahiye, Urdu hamara qeemti asaasa hai,) we should protect Urdu because it is our heritage we should protect and safeguard our language and the other class....

369 T: You have to write on your own. (Wahan pe ap ki raaye nahi poochi jaye gi $k$ is tasweer ko dekh k) your opinion will not be asked about the picture what you assess? What you take on get from that very picture.

412 T: If you have to teach the writing skills to the little kids, (ager ap ne kindergarten ko prahana hai to us k liva bacchon ko kesay ap parhaevin ge?) how would you teach the children at kindergarten? So how can you teach?

420 T: Start talking about the economic disparity and the present situation in Pakistan but (ap wahan pe qaboo nahi ker rahev) you are not controlling there.

428 T: I just thought to prepare handouts (ap tak pohanchey hi nahi hain, ager ap chahtey hain to) you didn't get them. Do you want these? Should I distribute the handouts for you?

3.2.3 Inter-Sentential Patterns Of Code-Switching of Female Teacher No.3

This teacher provided numerous examples of code-switching. She provided thirty six examples of ISS and these switches occurred at word level, phrase level and sentence level. The following table provides details of ISS uttered in her session. 
Table 7. Inter-sentential pattern of code-switching of female teacher No.3

\begin{tabular}{ll}
\hline Theme & Number of utterances \\
\hline Inter-sentential pattern of CS & 36 \\
\hline
\end{tabular}

The following examples are extracted from the transcription of female teacher No.3 to highlight the ISS:

71 T: Ok, ok, all right. (Jee, nahi ap ne bohat bta diva hai. thehar jaein zara. Jee madam salma??) Yes please, no, you have told a lot, now please wait for sometime. Yes madam Salma??

75 T: Ok, anybody else?? (Ap ooncha haath khara ker dein, kuch nahi hota) please raise hand high, nothing will happen

93 T: (Eik Yehi humaray haan ka problem hai na zada kah) this is the common problem we have that people will...Psychologically. You have to keep in your mind the level of your students and level of your each student. (Yeh nahin keh aap is ka zahan main rakhain us ka chorr dain theek hai na.) You can't keep the level of one student in mind and ignore the other. Level of each student.

99 T: ( . )What is communication? (Hum kehtain hain na jee communication honi chahay falana hoona chahiay yeh hoona chahiay.) We sav that there must be communication, this should be done, that should be done

186 T: This score is valid or this test is valid. How can I say this score is valid? (Koi bta sakta hai?) can somebody tell?

221 T: (Theek hai nain dil balliyon uchal raha hota hai teacher ka daikha na saray paraishan ho gav) The teacher feels happy at that time that she has made worried all the students, that is the face validity.

223 T: You have prepared that test, how is it possible. (us waqt mai ne barev josh mai banava tha ab mujhey samajh hi nahi aa rahi kesay kerna hai.) At that time I made it enthusiastically but now I don't know how to score it. When you don't know how you can expect from student he can do this. Sometimes you notice whenever you receive your paper(dhai dhai safay likhay hootay hain. Theek hai). two and a half page is written, ok?? What happens from the supervisor that two and a half pages have been written and you think oh what I have done!

337 T: And comparatively difficult words for writing. Keep this thing in your mind that sometimes we need comparatively easy words so we can communicate.(Theek hai na? kaisay aap kisi ko koi mushkaal word day dain gay to woh to peraishan hoo jai ga. Jaisay) right?? As if you give a difficult to someone, he'll surely be worried as one of the person at some university; I don't want to mention that university. Otherwise if you use very difficult words (theek hai nai moon teda kar keh baar baar English bolnay ki koshish karengay) right, trying to speak native like English at that time you will not be.

353 T: The problem here is that when we study and when we understand reading is sometimes we find difficulty we keep on looking sentences (her 2 minute baad humain dictionary kholni hoti hai check karna hoota hai) after every two minutes we have to open the dictionary and check it

358 T: (haan ab huey hain na haath kharey) now you have raised hands. ( $h$ ) you, you, you, what kind of problems you people face?? Excuse me, please here

380 T: Fluency is needed because firstly you have to speak. What is our problem we can't speak $\underline{\text { (Hum sub }}$ kay saath yeh masla hoota hai.) we all face the same problem.

382 T: (matlab baat main nain aap ko samjha di hai laikin ulta bool dia hai.) I've made you clear but have spoken wrong. So at that time 'I respect you' (aap ka adab karta hoon ya karti hoon ya jo bhi.) I respect you , (theek hai) right?? (Yeh nahin keh koi aap nain baat kuch aur kahi hai, kaha un se kuch aur hai, mang aap kuch aur rahi hain.) It should not be like this that you have asked them something else and expecting something else. No, no ambiguity yes, next (( )).

384 T: (Matlab yeh na hoo na keh dhai safay ka aap ka question ho) means the question should not be of two and a halfpage, two and a half page, ok, two and a half page and you are doing it, reading it and 35 minutes are gone. 


\subsubsection{Inter-Sentential Pattern of Code-Switching of Female Teacher No.4}

In this session, female teacher No.4 provided a small variety of ISS in comparison with female teacher No 2 and 3. She switched code more than seventeen times at sentence level. The following table provides details of switched utterances of her session.

Table 8. Inter-sentential pattern of code-switching of female teacher No.4

\begin{tabular}{ll}
\hline Theme & Number of utterances \\
\hline Inter-sentential pattern of CS & 17 \\
\hline
\end{tabular}

The following examples of code-switching are taken from transcription No.4 to give the highlights of code-switched utterances.

112 T: So I was saying ( $k$ dekhein ager dekha jeve to) If we observe, first year level, (generallv dekha jave to) if we generally observe first year student ( ).

$115 \mathrm{~T}$ : Actually this is the problem with the syllabus designers // they think the students should be,(ager who nahi kerty to unhein kerna chahive) if thev don't do, they must do

123 T: And that time, it should be only students' time in the classroom. it should not be the time of the exam. (Exams ko to koi bither nahi kerta.) nobody bothers about exams .

127 T: So if the students they learn vowels, then they can easily insert vowels, (consonants sikhave baghair vowels nahi sikhaney chahiyein). Don't teach vowels without teaching consonants. Let the students know how to read words. If they can read out words then you can teach them to read out sentences. (Ager un becharoon ko alafaz hi nahi abhi bnany aatev, va words hi ki jo, peachan nahi kerny aatev, to un ko sikhana,) If those poor souls don't know how to make words, or they can't recognize words, so to teach them. Sentence reading, it is useless because the basic component of the sentence is word.

181 T: (Us ko kahan use kerna hai, kis tareeqev se use kerna hai.) Where to use and how to use it. [ ] The language functions, the syllabus should contain the language functions this means that the students will be able to use language in real-life.

191 T: This is very, very important in a syllabus. (Topic to hai us ko kerna kya hai?) There is a topic but what to do with it? Will they be able to write about father's advice? These days the topic should be load shedding.

203 T: You people are four already, Three? either you can join them or one of you can, you are already four, (ap ko koi masala nahi, va ap in ko join ker lein,) You have no problem, vou can join them. just join them for a short while. You people are four, two are here, three?? One of you can come and join, (ap agev a jaien, ap dono peechey chaly jaein, ) You come in fron and both of you go at the back. Both of you can go at the back.

205 T: But there are two people at the back, (ap dono phir peechev chalv jaein.) You both go at the back then. They are four, (ap mai se koi ye peechey walon key saath mil ker four ka group bana lein,) Anyone of you join those sitting at the back and make a group of four. Three and two, and that is five and that is six, (ap kindly vahan a jaein, ager ap ki narazgi nahi hai to,) You kindly come here if you are not angry $($.$) Now each member of the group will get a copy of the syllabus, I think everywhere there are$ four people, (nahi nahi agev, yeh in kev saath bathive, ap please thora sa) No, no, at the front, sit with them, you please a little( ()).

\section{Results}

The representative examples indicate that ISPCS were used by the teachers in the EFL classrooms to accomplish different functions. However, the analyses of the sessions indicate that all the eight teachers used ISS but some of the teachers' switches were not in a great number as compared to the switches of the other teachers. Furthermore, on the basis of data analysed, female teacher No.2 provided a great number of ISS. Her delivery code was other than target language and due to the same reason she provided extensive examples of ISS. It shows that she could not extend her talk in the target code throughout the session. It is significant to reflect that all the teachers provided examples, whether more or less, related to ISS. All the tables provided before the analysis of the session are collated in the following table. 
Table 9. Distribution of ISPCS among the male and female teachers

\begin{tabular}{lll}
\hline & \multicolumn{2}{l}{ Number of code-switched utterances related to inter-sentential patterns } \\
\hline Name & $\begin{array}{l}\text { Number of inter-sentential } \\
\text { utterances }\end{array}$ & $\begin{array}{l}\text { Difference in male and female } \\
\text { utterances }\end{array}$ \\
Male teacher No.1 & 13 & \\
Male teacher No.2 & 55 & \\
Male teacher No.3 & 8 & \\
Male teacher No.4 & 9 & \\
Total male utterances & $\mathbf{8 5}$ & \\
Female teacher No.1 & 68 & \\
Female teacher No.2 & 82 & $203-85=118$ \\
Female teacher No.3 & 36 & \\
Female teacher No.4 & 17 & \\
Total female utterances & $\mathbf{2 0 3}$ & \\
Grand Total of male and female & 288 & \\
utterances & & \\
\hline
\end{tabular}

Table No. 9 reflects that female teachers are more inclined towards ISPCS but senior female teachers' numbers of ISS are comparatively less as compared to young female teachers. And the same results are found in the category of male teachers, and on the basis of these results it can be verified that trends of ISPCS are more prevalent in younger/less experienced male and female EFL teachers. The results of the study showed that all the teachers, both male and female, presented a variety of ISS. This kind of code-switching is particularly prevalent in the teacher talk as Martin-Jones calls it discourse related code-alternation (Martin-Jones, 2000, p. 6). Moreover, Jacobson (1990) proposes that "teacher may code-switch at some key points such as when concepts are important, when the students are getting distracted, or when a student should be praised or reprimanded."

\section{Conclusion}

On the basis of the results, it was found that it was an unavoidable and inevitable phenomenon because teachers' code-switching was mainly in the ISS. In the EFL classrooms, interacants must focus on the content and the language of the discourse. And for this purpose, the teacher must know how he has to focus on language and contents without breaking links of the classroom discourse. During the analysis of the sessions, it was observed that all the teachers followed the self determined course for the use of codes and due to this reason the number of switched utterances vary at a higher level. In a Pakistani system of education, English also serves a dual role: As a compulsory subject and as a medium of instruction. In public sector schools, English is used as a content subject and its use as a medium of instruction is not clear in the language policy and this uncertainty results in code- switching among the interactants of EFL classrooms. Therefore, after analysing the situation in the EFL classrooms, the researchers recommend more conscious and cognizant use of inter-sentential switches particularly at the level of proficient bilinguals. Focusing on the indications of the results, it can be recommended that a clear language policy should be devised for the promotion of effective interactional patterns in the EFL classroom. The same can be substantiated from the above outlined literature review that code switching may facilitate language development as a mechanism for providing language samples and may also be utilised as a teaching method for teaching second languages. Irrespective of the benefits of ISS, these switches can cause interference in the acquisition of the target language code if they are not used carefully only as a teaching method/aid. However, this situation demands immediate attention of the policy planners to determine the prerequisites of ISS for the better development of interactional patterns in the EFL classrooms. Accordingly, the nature of ISS patterns of interaction should be further traced out to understand the interactions between teachers and students. In this paper, the researchers have laid a foundation for future researches that may explore further dimensions of teachers' and students' talk in the EFL classrooms. Finally, a meaningful language use in the context and flexibility of the curriculum are underlined as a crux of the study. The most outstanding recommended actions are as follows: Teachers must be well aware of students' proficiency level because the sensible combination of native and target languages can enhance the learning competence of the students. Furthermore, a language philosophy values any 
language variation for the purpose of human communication; hence the dual use of language is the only way to establish a point of deviation from TL in an EFL classroom if based on the urgent needs of the learners. Instructional activities for linguistically diverse students must not only be interactive in nature but also be rich in the cultural context for comparative and contrastive analyses of native and target language connections.

\section{References}

Aguirre, A. (1988). Code-switching, intuitive knowledge, and the bilingual classroom. In H. S. Garcia, \& R. C. Chavez (Eds.), Ethnolinguistic issues in education (pp. 28-38). Lubbock, TX: Texas Tech University, College of Education.

Andeson, C. U., \& Anderson, S. (1999). Growing up with Two Languages: A practical Guide. London; New York: Routledge.

Atkinson, D. (1993). Teaching Monolingual classes: Using L1 in the classroom. Harlow: Longman Group Limited.

Auer, J. (1995). The Pragmatics of Code-Switching: A Sequential Approach. In L. Milroy, \& P. Muysken (Eds.), One Speaker, Two Languages: Cross-disciplinary Perspectives on Code-switching (p. 201). Cambridge: University Press. http://dx.doi.org/10.1017/CBO9780511620867.006

Auerbach, E. R. (1989). Toward a social-contextual approach to family literacy. Harvard Educational Review, $59,165-181$.

Baker, C., \& Jones, P. S. (1998). Encyclopaedia of Bilingualism and Bilingual Education. Clevedon, UK: Multilingual Matters.

Bootzin, R. R., Bower, G. H., Zajonc, R. B., \& Hall, E. (1986). Psychology Today: An Introduction. Random House: New York.

Brice, A. (2000). Code switching and Code mixing in the ESL Classroom: A Study of Pragmatic and Syntactic Feature. Advances in Speech Language Pathology. Journal of the Speech Pathology Association of Australia, 20(1), 19-28.

Burenhult, N., \& Flyman-Mattson, A. (1999). Code switching in Second Language Teaching of French. Retrieved June 20, 2007, from http://www.google.com/search?q=cache:GbFBmAtk8TAJ:www.ling.lu.se/disseminations/pdf/47/Flyman_B urenhult.pdf+classroom + discourse + in + bilingual + context\&hl=en

Burns, A. (1999). Collaborative Action Research for English Language Teachers. U. K: Cambridge University Press.

Cook, V. (1991). Second language learning and language teaching. London: Edward Arnold.

Corder, S. P. (1981). Error analysis and interlanguage. London: Oxford University Press.

Crystal, D. (1997). The Cambridge Encyclopaedia of Language. Cambridge: Cambridge University Press.

Di Sciullo, A. M., Muysken, P., \& Singh, R. (1986). Government and Code-mixing. Journal of Linguistics, 22, 1-24. http://dx.doi.org/10.1017/S0022226700010537

Eastman. (1995). Codeswitching, 123-142. Clevedon: Multilingual Matters.

Eisner, E. (1992). The Enlightened Eye: Qualitative Inquiry and Enhancement of Educational Practice. New York: Macmillan Publishing.

Ellis, R. (1985). Understanding second language acquisitions. Oxford: Oxford University Press.

Galasso, J. (2001). The Development of Code switching: Minimalist Constraints and the Role of Checking Theory.

Genesee, F., Paradis, J., \& Crago, M. B. (2004). Dual Language Development \& Disorders: A Handbook on Bilingualism \& Second Language Learning. Baltimore, Maryland: Brookes.

Gibbons, J. (1979). Code-mixing and koineising in the speech of students at the University of Hong Kong. Anthropological Linguistics, 21, 113-23.

Green, Kantor, \& Rogers. (1990). Exploring the complexity of language and learning in the classroom. In B. Jones, \& L. Idol (Eds.), Educational values and cognitive instruction: Implications for reform (pp. 333-364). Vol. II. Hillsdale, NJ: Erlbaum). 
Grosjean, F. (1982). Life with two Languages: An Introduction to Bilingualism. Cambridge, Massachusetts: Harvard University Press.

Gulzar, M. A. (2010). Classroom Discourse in Bilingual Context: Effects of Code-switching on Language learning. VDM Publishing House, Germany.

Gulzar, M. A. (2010). Code-Switching: Awareness about Its Utility in EFL/ESL Classroom Discourse. Bulletin of Education and Research, 32(2), 1-14. Institute of Education and Research, University of the Punjab, Pakistan.

Gumperz, J. J. (1976). The sociolinguistic significance of conversational code-switching. (Working Papers of the Language Behavior Research Laboratory, No. 46). Berkeley: University of Califomia.

Gysels, M. (1992). French in Urban Lubumbashi Swahile: Code-switching, borrowing or both? Journal of Multilingual and Multicultural Development, 13, 41-56. http://dx.doi.org/10.1080/01434632.1992.9994482

Hakuta. (1986). Mirror of Language: The Debate on Bilingualism (pp. 11-12). New York: (Review by Genesse 1987 in Miami and Kennedy 1991).

Hamers, F. J., \& Blanc, A. H. M. (1989). Bilinguality and Bilingualism. Cambridge University Press.

Hammink, J., \& McLaughlin, B. (2000). A Comparison of Code switching Behaviour and Knowledge of Adults and Children. Retrieved March 28, 2007, from http://www.google.com

Haugen, E. (1987). Blessing of Babel: Bilingualism and Language Planning Problems and Pleasures. Berlin \& New York: Montonde Gruyter. Retrieved http://www.umanitoba.ca/education/symposium03/documents/MacKay03.pdf

Heller, M. (1988). Codeswitching: Anthropological and SociolinguisticPerspectives. Berlin: Mouton de Gruyter. http://dx.doi.org/10.1515/9783110849615

Huerta, A. G. (1977). The acquisition of bilingualism: A code-switching approach. In Working papers in sociolinguistics. Austin, TX.

Jacobson, R. (1985). Title VII demonstration projects program in bilingual instruction methodology (final report). San Antonio, TX: Southwest independent school district.

Johnson, K., \& Johnson, H. (Eds.). (1998). Encyclopaedic Dictionary of Applied Linguistics. Oxford: Oxford University Press.

Judith, \& Wallat. (1981). Ethnography and language in educational settings. ABLEX Pub.Co.

Kachru, B. B. (1978). Code Mixing as Communicative Strategy in India: In International Dimension of Bilingual Education (ed). Jame E. Alatis George Town University Press.

Kamwangamalu, N. M. (1992). Mixers and Mixing English across Cultures. World Englishes, 11(2/3), 173-181. http://dx.doi.org/10.1111/j.1467-971X.1992.tb00062.x

Klein, W. (1986). Second language acquisition. Cambridge, London: Cambridge University Press. http://dx.doi.org/10.1017/CBO9780511815058

Labov, W. (2010). Principles of linguistic change cognitive and cututral factor. University of Michigan Press. http://dx.doi.org/10.1002/9781444327496

Lipski, J. M. (1978). Code-switching and bilingual competence. In M. Paradis (Ed.), Fourth LACUS Forum (pp. 263-277). Columbia, S. C. Hornbeam Press.

LiWei. (2000). The Bilingualism Reader. London; New York: Routledge.

Macswan, J. (1999). A Minimalist Approach to Intra-sentential Code switching. New York; London: Garland Publishing.

Makay, L. S., \& Hornberger, H. N. (1996). Sociolinguistics and Language Teaching. New York: Cambridge University Press.

Martin-Jones, M. (1995). Code-switching in the Classrooms: Two Decades of Research. In L. Milroy, \& P. Muysken (Eds.), One Speaker, Two languages: Cross-disciplinary Perspectives on Code-switching (pp. 90-112). Cambridge: University Press. http://dx.doi.org/10.1017/CBO9780511620867.005

Martin-Jones, M. (2003). Teaching and Learning Bilingually: Towards an Agenda for Qualitative Classroom -Based Research. Retrieved January 20, 2008, from http://www.aber.ac.uk/ merwww/general/papers/mercSym-03-04-08/marilyn.doc 
Mehan, H. (1982). The Structure of Classroom Events. In P. Gilmore, \& A. Glatthorn (Eds.), Children In and Out of School (pp. 59-87). Centre for Applied Linguistics.

Merritt, M. A. (1999). Socialising Multilingualism: Determinants of Code switching in Kenyan Primary classroom. In C. M. Eastman (Ed.), Code switching (pp.103-121). Clevedon: Multilingual Matters LTD.

Milroy, L., \& Muysken, P. (1995). Introduction: Code-switching and Bilingualism Research. In L. Milroy, \& P. Muysken (Eds.), One Speaker, Two languages: Cross-disciplinary Perspectives on Code-switching (pp. 1-14). Cambridge: University Press. http://dx.doi.org/10.1017/CBO9780511620867.001

Myers-Scotton, C. (1993). Dueling languages: Grammatical Structure in Code switching. Oxford: Clarendon.

Pfaff, C. W. (1987). First and second language acquisition. MA: Newbury House Publications, Cambridge.

Poplack, S. (1980). Sometimes I'll Start a Sentence in Spanish y Termino enEspanol: Toward a Typology of Code-switching. Linguistics, 18(233-234), 581-618.

Romaine, S. (1989). Bilingualism. USA: Black Well Publisher.

Sankoff, D., \& Poplack, S. (1981). A Formal Grammar for Code-Switching. Papers in Linguistics, 14(1-4), 3-45. http://dx.doi.org/10.1080/08351818109370523

Selinker, L. (1972). Interlanguage. International Review of Applied Linguistics, 10, 209-231. http://dx.doi.org/10.1515/iral.1972.10.1-4.209

Skiba, R. (1997). Code switching as a Countenance of Language Interference. The Internet TESL Journal, 3(10). Retrieved June 11, 2007, from http://www.aitech.ac.jp/ iteslj/Articles/Skiba-CodeSwitching.html

Skinner, B. F. (1957). Verbal Behaviour. Appleton-Century-Crofts: New York. http://dx.doi.org/10.1037/11256-000

Skutnabb-Kangas, T. (2000). Linguistic Genocide in Education or Worldwide Diversity and Human Rights. London: Erlbaum.

Skutnabb-Kangas, T., \& Cummins, J. (Eds.) (1988). Minority Education from Shame to Struggle. Cleveden, Avon: Multilingual Matters.

Stevens, R. (1983). A theoretical model of the language learning/language teaching process. Working Papers On Bilingualism, 11, 129-152.

Valdds-Fallis, G. (1981). Code-switching as a deliberate verbal strategy: A microanalysis of direct and indirect requests among bilingual Chicano speakers. In R. P. Durin (Ed.), Latino language and communicative behavior (pp. 95-108). Norwood, N. J.: Ablex.

Van Lier, L. (1988). The Classroom and Language Learner: Ethnography and Second Language Classroom Research. London: Longman.

Vygotsky, L. (1962). Thought and Language. Cambridge, MA: MIT Press. http://dx.doi.org/10.1037/11193-000

Weinreich, U. (1953). Languages in Contact. The Hague: Mouton.

Woolard, K. (1985). Language Variation and Cultural Hegemony. American Ethnologist, 12(4), 738-748.

Woolford, E. (1983). Bilingual code-switching and syntactic theory. Linguistic Inquiry, 14, 225-252. http://dx.doi.org/10.1525/ae.1985.12.4.02a00090

Zentella, A. C. (1981). Ta bien, you could answer me en cualquier idioma: Puerto Recan Code-switching in bilingual classrooms. In R. P. Duran (Ed.), Latino Language and Communicative Behaviour (pp. 95-107). Norwood, New Jersey: ABLEX Publishing Corporation.

\section{Appendix}

* T 1 identify teachers using numbers ( $\mathrm{T} 1, \mathrm{~T} 2, \mathrm{~T} 3, \mathrm{~T} 4)$

* S 1 identify students, using numbers ( $\mathrm{S} 1, \mathrm{~S} 2, \mathrm{~S} 3$ etc)

* Ss unidentified group of students or whole class, speaking together

(words) parenthesis surrounding a word or set of words indicate uncertainty about the transcription.

Parentheses around an empty space on a line indicate an utterance incomprehensible to the researcher. 
"words" A word or set of words with asterisks indicate soft utterances.

(( )) Double parenthesis surrounding statements provide either scenic description or non-verbal action description.

(. ) Parentheses around a dot on a line or between lines indicate a pause or lapse of time.

[ Open brackets indicate the onset of simultaneous talk between the linked utterances.

$=$ Equal signs come in pairs, at the end of one line or utterance, and at the start of a subsequent one; the talk linked by equal signs (whether by different speakers or same speaker) is continuous and is not interrupted by any silence or other break.

// Double slashes indicate a point at which one speaker overlaps another.

?? $\quad$ Punctuation marks indicate intonation contours (rising and falling in intonation in question); they do not indicate grammatical status i.e., question.

out Underlining indicates emphasis.

(h) The letter ' $h$ ' in parentheses indicates a common laughter.

Today Utterance bolded and in italics indicates that utterance was actually said in Urdu but their translation is provided for the purpose of understanding the transcripts by English readers.

\section{Copyrights}

Copyright for this article is retained by the author(s), with first publication rights granted to the journal.

This is an open-access article distributed under the terms and conditions of the Creative Commons Attribution license (http://creativecommons.org/licenses/by/3.0/). 